\title{
Behavioural Social Work
}


Also by Barbara L. Hudson

Social Work with Psychiatric Patients 


\title{
Behavioural Social Work An Introduction
}

\author{
Barbara L. Hudson \\ and \\ Geraldine M. Macdonald
}

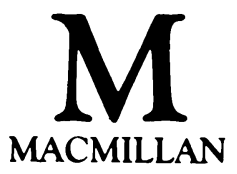


(c) Barbara L. Hudson and Geraldine M. Macdonald 1986

All rights reserved. No reproduction, copy or transmission of this publication may be made without written permission.

No paragraph of this publication may be reproduced, copied or transmitted save with written permission or in accordance with the provisions of the Copyright, Designs and Patents Act 1988, or under the terms of any licence permitting limited copying issued by the Copyright Licensing Agency, 33-4 Alfred Place, London WCIE 7DP.

Any person who does any unauthorised act in relation to this publication may be liable to criminal prosecution and civil claims for damages.

First published 1986

Reprinted 1988, 1991

Published by

MACMILLAN EDUCATION LTD

Houndmills, Basingstoke, Hampshire RG21 2XS

and London

Companies and representatives

throughout the world

Filmsetting by Vantage Photosetting Co Ltd

Eastleigh and London

British Library Cataloguing in Publication Data

Hudson, Barbara L.

Behavioural social work : an introduction.

1. social case work

I. Title II. Macdonald, Geraldine M.

361.3'2 HV43

ISBN 978-0-333-36133-7 ISBN 978-1-349-18294-7 (eBook)

DOI 10.1007/978-1-349-18294-7 
For Kenneth and Ezra Macdonald 


\section{Contents}

Preface ix

Acknowledgements $\quad$ xi

Introduction 1

Part 1

1 Why Behavioural Social Work?

2 Theories of Learning 22

3 How to Begin a Behavioural Programme: I 60

4 How to Begin a Behavioural Programme: II 78

5 Behavioural Intervention Procedures I: Respondent and Operant Procedures

6 Behavioural Intervention Procedures II: CognitiveBehavioural, Self-Management Procedures and Combinations of Procedures

7 Groupwork and Community Work 165

\section{Part 2}

8 Parents and Younger Children

9 Older Children and Teenagers: With Special Reference to Delinquency

10 Mental Handicap

11 Depression and Anxiety

12 Older People

13 Work and Money Problems

Afterword

Guidelines for Further Reading 258

Bibliography 262

Author Index 276

Subject Index 280 


\section{Preface}

Behavioural social work has much to offer from both an ethical and a practical standpoint. This is not to suggest that behavioural theories and methods will suffice to cope with all of the issues and tasks that confront social workers. We need a wide range of knowledge from the contributory disciplines besides psychology, and from psychology we need other knowledge, such as an understanding of normal development and abnormal functioning. And we require additional skills, such as obtaining material resources and finding our way through the maze of bureaucracy and political power structures. Nevertheless, a behavioural approach can help with a large chunk of our day-to-day work, from assessing situations and writing reports to intervening with individuals and groups and seeking to modify the behaviour of other people who exert an influence on our clients' lives.

This book will give you a basic understanding of the theories from which behavioural procedures have been derived, and of how the procedures are applied in practice. In the latter part of the book we illustrate some of the uses of behavioural procedures with several client groups and problem areas taken separately. We hope to demonstrate the applicability of the behavioural approach to the breadth of problems encountered by social workers. Some areas are not covered in any depth, such as the work of hospital and residential workers, as this book is aimed primarily at those 'in the field'. However, many of the interventions discussed, and the chapters on learning theory and assessment, should be useful to social workers in all settings.

A word about our use of references. Since this is an introductory text, we have not cited references for every statement for which there is research evidence available; in the main we have given key 


\section{x Preface}

references on important topics and references where statements in the text may give rise to controversy.

In order to avoid accusations of sex discrimination, and to avoid the clumsiness of 'she/he', etc., we have used male and female pronouns randomly to denote workers, clients and others.

University of Oxford

BARBARA L. HUDSON GERALDINE M. MACDONALD 


\section{Acknowledgements}

Parts of the manuscript were read by Michael Crowe, Clive Hollin, Derek Johnston, Roger McAuley, Kenneth Macdonald, Pauline McDonnell, Ilona McDowell, Roger Morgan, Mike Noble, Ann Nursey, Brian Sheldon and Christine Stevens. We had permission to use case material (suitably disguised) from some of the aforementioned, and from Ian Mathews, Sarah Ainsworth and Howard Lomas. We are grateful to them all, and errors and omissions that remain are our own responsibility.

Much of the typing was done by Rachael Lawrance fast and expertly.

We thank the Macmillan Press, Pergamon Press, Roger McAuley, Judy Hutchings and Sheldon Rose for permission to reproduce published material.

University of Oxford

B.L.H.

G.M.M. 